Palavras-chave: burocracia, participação, orçamento participativo, democracia, igualdade, liberdade.

\title{
Por que as empresas investem em responsabilidade social?
}

Cinara Gomes de Araújo

Curso: Doutorado em Sociologia

Data de defesa: 30 de outubro de 2006

Orientador: Prof. Dr. Danilo Nolasco Cortes Marinho

\section{Resumo}

A partir dos anos 90, as empresas no Brasil aumentaram os investimentos em projetos sociais, passaram a defender padrões mais éticos de relação com seus públicos de interesse (fornecedores, funcionários, clientes, governo e acionistas) e práticas ambientais sustentáveis. Sob o rótulo de "responsabilidade social", foi incluído um conjunto de normas e práticas que se tornou condição para garantir lucratividade e sustentabilidade aos negócios.

Norteou a pesquisa a hipótese de que tais mudanças não decorrem de condicionamentos infligidos pelo consumidor ou pelo mercado, mas da interpretação que os gestores fazem do cenário e do que entendem ser a melhor conduta para a empresa. Por isso, a pesquisa procurou descrever o processo social e histórico que levou à construção de tal associação, os principais atores que a tornaram hegemônica, o perfil dos gestores e os fatores estruturais que facilitaram a difusão das normas de responsabilidade social no 
ambiente corporativo. Procurou-se identificar os atores que fizeram com que normas presentes no ambiente institucional penetrassem nas empresas e influíssem na sua estrutura organizacional e na maneira como se relacionam com seus públicos de interesse. Para tanto, tomou-se como marco teórico o Novo Institucionalismo na Sociologia e Economia.

A pesquisa empírica dividiu-se em três blocos. Inicialmente, foi feita a análise dos documentos das principais Organizações NãoGovernamentais (ONGs) que atuam na área de responsabilidade social, a fim de se conhecer as contribuições que trouxeram e as ações de mobilização que empreenderam. Depois, foram realizadas entrevistas abertas com os gestores das áreas de responsabilidade social de empresas do comércio e setor bancário e aplicado um questionário a uma amostra selecionada a partir do ranking da revista Exame (2005).

A partir da história profissional e de participação política dos gestores, constatou-se que eles são tendentes a se identificar com o conteúdo de responsabilidade social, ou seja, são comprometidos com a causa. Na análise dos questionários, observou-se que as empresas aumentam os investimentos em valores brutos na área social quanto mais crescem em receita líquida, resultado operacional, número de empregados e participação em ONGs, e quanto menor a exposição ao consumidor. Também as empresas tendem a publicar balanço social quanto mais participam de ONGs.

Não se constatou relações de formalização de áreas de RSE com as variáveis antes citadas, com exceção de número de empregados. No entanto, verificou-se, nas entrevistas abertas, que são áreas ainda muito recentes, que ainda estão sendo estruturadas.

Palavras-chave: responsabilidade social, política social privada, organização, Novo Institucionalismo, Terceiro Setor, Sociologia Econômica, elites administrativas, burocracia. 